\title{
SEJARAH SINGKAT PERKEMBANGAN TAFSIR AL-QUR'AN
}

\section{Muhibudin}

\author{
Fakultas Agama Islam, Universitas Islam As-Syafiíyah, Indonesia \\ muhibudin.fai@uia.ac.id
}

\begin{abstract}
Tafsir adalah ilmu untuk memahami Kitab Allah yang diturunkan kepada Rasul Allah SAW, penjelasan mengenai makna-makna Kitab Allah, serta mengesensikan hukum-hakam dan hikmah-hikmahnya. Artikel ini membahas tafsir sebagai sebuah proses penjelasan yang dilakukan oleh penafsir dalam hubungannya yang langsung dengan ayat-ayat al-Qur'an, sehingga terjadilah penyingkapan makna-makna al-Qur'an dan penjelasan maksudnya; sejarah tafsir yang membahas tentang pergerakan tafsir dan kehidupan para mufassir; beserta sumbangannya (tabaqat al-mufassirin); dan metode-metode para mufassir untuk mengetahui pendapat pemikiran yang menjadi kecenderungan dan fahaman mereka yang beragam yang mempengaruhi karakteristik tafsir mereka.

Interpretation is the science of understanding the Book of Allah revealed to the Messenger of Allah, the explanation of the meanings of the Book of God, as well as legal sanctions and its other subject discussions. This article discusses interpretation as an explanation process carried out by the interpreter in direct connection with the verses of the Qur'an, so there was the unfolding of the meanings of the Qur'an and the explanation of its purpose; a history of commentaries that discusses the movements of the interpreters and the lives of the commentators; along with their donations (tabaqat al-mufassiriin); and the methods of the commentators to know their method of thought, their tendency and various understanding that affect their characteristics comments.
\end{abstract}

Keywords: Al-Qurán; Tafsir; Mufassir; Metode Tafsir; Marhalah Tafsir 


\section{Definisi Tafsir}

Secara etimologi perkataan tafsir biasa diartikan menyingkap (الكشف) dan menjelaskan البيان) التفسرة atang الفسر Ianya diambil dari perkataan berarti memeriksa pesakit melalui air kencingnya ${ }^{2}$. Kata tafsir sendiri disebutkan di dalam surat al-Furqān ayat 33:

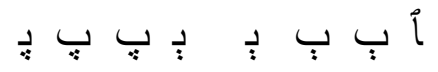

Artinya: "Dan mereka tidak membawa kepadamu sesuatu kata-kata yang ganjil (untuk menentangmu) melainkan Kami bawakan kepadamu kebenaran dan penjelasan yang sebaik-baiknya (untuk menangkis segala yang mereka katakan itu).

Secara terminologi, tafsir merujuk kepada ilmu untuk memahami Kitab Allah yang diturunkan kepada Rasul Allah s.a.w, penjelasan mengenai makna-makna Kitab Allah dan mengeluarkan hukum-hakam dan hikmah-hikmahnya. ${ }^{3}$ Definisi terminologi tafsir para ulama tafsir terdahulu hampir semuanya mendekati dengan apa yang disebutkan oleh al-Zarkasyi tadi, separti yang ditakrifkan oleh al-Aṣbahānī ${ }^{4}$ ataupun Abū Hayyān. ${ }^{5}$

\section{Ilmu Tafsir dan Perkembangannya}

Sesungguhnya ilmu tafsir adalah lapangan yang luas yang memuat tiga hal utama sekaligus:

2.1. Tafsir sebagai sebuah proses penjelasan yang dilakukan oleh penafsir dalam hubungannya yang langsung dengan ayat-ayat al-Qur'an, sehingga "terjadilah penyingkapan makna-makna alQur'an dan penjelasan maksudnya" separti yang dikatakan oleh al-Rāghib al-Aṣfahānī, ${ }^{6}$ atau

\footnotetext{
${ }^{1}$ al-Sabt, Khalid Ibn 'Uthmān, Qawācid al-Tafšrir, Dār Ibn 'Affān, t.tp, 1421H, jil.1, hlm.25

${ }^{2}$ Ibn Manzūur, Muḥammad ibn Makram, Lisān al- ${ }^{c}$ Arab, Dār Șādir, Bayrūt, t.th, jil.5, hlm.55

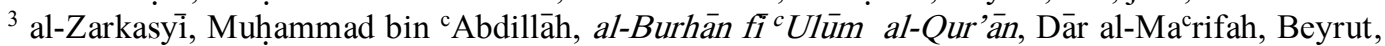
jil.1, hlm.13

${ }^{4}$ al-Suyūṭị, Jalaluddin, al-Itqān fí ' Ulūm al-Qur'an, Dār al-Kutub al-cilmiyyah, Bayrūt, 1995, jil.2, hlm.382

${ }^{5}$ Ibid., hlm.382

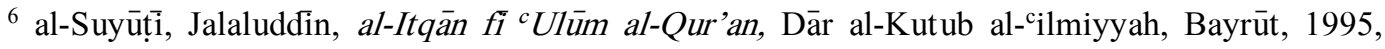
jil.2, hlm.382
} 
“mencari penjelasan makna lafaz-lafaz al-Qur'an dan yang dapat disimpulkan darinya baik secara ringkas mahupun luas", separti yang diungkapkan oleh Ṭāhir ibn ' ${ }^{\mathrm{A}} \overline{\mathrm{s} y u \bar{r}}{ }^{7}$

2.2. Sejarah tafsir yang membahas tentang pergerakan tafsir sesuai dengan sejarahnya yang panjang. Pembahasan ini membicarakan tentang kehidupan para mufassir, kehidupan dan sumbangannya yang biasa dibahas dalam ilmu tabaqāt al-mufassirīn yang dianggap sebagai salah satu cabang dari cabang ilmu sejarah juga. ${ }^{8}$

2.3. Dalam ilmu tafsir juga ada pembahasan tentang metode-metode para mufassir untuk mengetahui pendapat pemikiran yang menjadi kecenderungan dan fahaman mereka yang beragam yang mempengaruhi karakteristik tafsir mereka. Ilmu ini dikenal dengan ilmu Manāhij al-Mufassirīn. Dalam Majmuf Fatāwānya, ibn Taimiyah juga menyingggung masalah metodemetode tafsir di era beliau dan sebelumnya. Beliau mengomentari tafsir Ibn 'Ațiyyah alMuharrar al-Wajiz sebagai tafsir yang mengikuti sunnah dan selamat dari bid ${ }^{\mathrm{c}}$ ah. ${ }^{9}$ Adapun tafsir al-Tḥaclabi menurut beliau adalah tafsir yang mencampurkan antara yang sahihh, $\bar{a}_{\bar{a}}$ if dan maud $\bar{u}$, bahkan penulisnya pun beliau sebut sebagai حاطب ليل (pencari kayu bakar di malam hari yang tidak akan boleh membedakan mana kayu yang baik dan yang buruk) Berbeda dengan tafsir al-Baghāwī yang terjaga dari hadis-hadis palsu dan pendapat-pendapat yang bid'ah. ${ }^{10}$

Dalam perkembangan periode tafsir, Dr. Muhammad Husain al-Dhahabì membagi perkembangan tersebut berdasarkan periode zaman, beliau membagi kepada tiga periode yaitu: ${ }^{11}$

Periode pertama, zaman Rasul Allah s.a.w dan sahabat. Rasul s.a.w menyampaikan, menerangkan dan menjelaskan isi al-Qur'an. Jika ada diantara para sahabat yang berselisih atau tidak mengarti mengenai kandungan al-Qur'an, mereka merujuk langsung kepada Rasul s.a.w mengenai makna sebuah ayat al-Qur'an sekaligus penjelasannya. Setelah Rasul s.a.w wafat, para sahabat r.a menafsirkan al-Qur'an dengan sangat hatihati walaupun mereka menyaksikan bagaimana dan bila serta mengapa ayat-ayat al-

\footnotetext{
${ }^{7}$ Ibn ${ }^{\mathrm{c}} \bar{A}$ syūr, Muhammad ibn al-Ṭāhir, al-Tahrīr wa al-Tanwïr, al-Dār al-Saḥnūn li al-Nasyr, Tünis, 1997, jil.1, hlm.12

${ }^{8}$ Thāsy Kubri Zādah, Miftāh al-Sac ādah wa Miṣbāh al-Siyādah fi Mauḍư àt al-' Ulüm, Dār Kutub al-'Ilmiyyah, Bayrūt, 1985, jil.1, hlm.261

${ }^{9}$ Ibn Taimiyah, Ahmad ibn 'Abd al-Hạim, Majmūe Fatāwā ibn Taimiyah, Dār al-Waf', ttp, 2005, jil.13, hlm.361

${ }^{10}$ Ibid, hlm.354

11 Muḥammad Ḥusain al-Dhahabi, al-Tafsìr wa al-Mufassirūn, Maktabah Wahbah, Qāhirah, 2000, jil.1, hlm. 27
} 
Qur'an diturunkan dan walaupun mereka adalah أرباب الفصاحة والبيان (sangat fasih dan mahir dalam bertutur kata dan berhujah). Abu Bakar al-Siddiq r.a misalnya mengatakan: Bumi mana yang akan memangkuku dan langit mana yang menaungiku jika aku mengatakan di dalam kitab Allah apa yang tidak aku ketahui. ${ }^{12}$

Para sahabat r.a menafsirkan al-Qur'an dengan berpegang kepada tafsiran yang disampaikan oleh Rasul s.a.w kepada mereka. Salah satu kelebihan mereka adalah mereka yang menyaksikan langsung bagaimana, bila dan di mana ayat-ayat al-Qur'an turun kepada Rasul s.a.w sehingga mereka sangat faham apa makna, kandungan dan tujuan sesebuah ayat diturunkan. ${ }^{c} A b d u l l a h$ ibn Mas ${ }^{c} \bar{u} d$ r.a mengatakan: "Demi Allah yang tidak ada Tuhan selainNya, tidak ada ayat dari Kitab Allah yang diturunkan melainkan aku paling mengetahui kepada siapa ia diturunkan dan dimana diturunkan. Seandainya aku tahu adanya seseorang yang lebih mengetahui daripadaku tentang Kitab Allah boleh sampai kendaraan ke tempatnya maka pasti aku akan mendatanginya". ${ }^{13}$ Adapun yang paling terkenal daripada para sahabat dan yang paling banyak mengetahui tafsir al-Qur'an serta paling banyak meriwayatkan daripada Rasul s.a.w diantaranya adalah ${ }^{\mathrm{c} A l i}$ ibn Abi Țālib, ${ }^{\mathrm{c} A b d u l l a ̄ h ~ i b n ~ M a s}{ }^{\mathrm{c} u d,}{ }^{\mathrm{c} A b d u l l a h ~ i b n}{ }^{\mathrm{c}}$ Abbās dan Ubay ibn $\mathrm{Ka}^{\mathrm{c} a b} \cdot{ }^{14}$

Ketika menafsirkan ayat-ayat al-Qur'an, para sahabat r.a pertama-tama menelitinya dalam al-Qur'an sendiri, karena ayat-ayat al-Qur'an satu sama lain saling menafsirkan. Setelah itu, mereka merujuk kepada penafsiran Rasul s.a.w, sesuai dengan fungsi beliau sebagai penjelas terhadap ayat-ayat al-Qur'an. Sekiranya penjelasan tentang ayat tertentu tidak ditemukan di dalam al-Qur'an dan hadis, maka para sahabat berijtihad. Rengkasnya, pada zaman sahabat, ucapan, perbuatan, tindakan dan keputusan Rasul Allah s.a.w dijadikan sandaran untuk menafsirkan al-Qur'an.

Dr. Muhammad Husain al-Dhahabi kemudian menyebutkan keistimewaan tafsir pada zaman Rasul Allah s.a.w dan para sahabat baik berhubungan dengan kuantitas

\footnotetext{
12 al-Tabari, Muhammad ibn Jarīr, Jāmíc al-Bayān fỉ Ta'wìl Ay al-Qur'an, Muassasah al-Risālah, t.tp, 2000, jil.1, hlm.78

${ }^{13}$ Ibn Kathīr, Abu al-Fidā Ismā'il ibn 'Umar, Tafšir al-Qur'ān al- ${ }^{c}$ Ażìm, Dār al-Ṭayyibah, t.tp, 1999, jil.1, hlm.7

${ }^{14}$ al-Rūmi, Fahd ibn Sulaimān, Buhūth fi Ușūl al-Tafsīir wa Manāhijih, Maktabah al-Taubah, t.tp, 1419H, hlm.26
} 
maupun yang berhubungan dengan metodologi dan cara mentafsir, yaitu sebagai berikut: ${ }^{15}$

1. Al-Qur'an tidak ditafsirkan secara keseluruhan, tetapi hanya sebagian saja.

2. Sedikitnya perbedaan pendapat di antara para sahabat dalam memahami maknamakna al-Qur'an

3. Para sahabat merasa cukup puas dengan makna yang global.

4. Mencukupkan dengan penjelasan bertumpu kepada makna kebahasaan.

5. Amat sedikit istinbàt terhadap hukum-hukum fiqh dan sama sekali tidak ada tafsir madhhabi atau aliran tertentu

6. Belum ada proses pembukuan tafsir.

7. Menjadikan tafsir sebagai bahagian daripada hadis

Periode kedua, masa tabiin. Setelah generasi sahabat, para tabiin menafsirkan al-Qur'an dengan al-Qur'an, hadis Nabi dan pendapat para sahabat. Selain itu baru mereka mengembangkan penafsiran sendiri berdasarkan ijtihad. Pada masa tabiin, tafsir belum merupakan sebuah disiplin ilmu yang berdiri sendiri. Tafsir masih merupakan bahagian dari hadis. Ini menunjukkan dengan jelas bahwa tafsir tidaklah sewenang-wenang namun selalu terkait dengan apa yang telah dilakukan oleh Rasul Allah s.a.w dan para sahabat. Berkata Imam Mujāhid r.a ulama tafsir kalangan tābi ${ }^{c i ̄ n}$ dan salah seorang murid Ibn 'Abbās yang paling dipercayai: “Aku memperdengarkan al-Qur'an kepada Ibn 'Abbās sebanyak tiga kali, dimana aku selalu berhenti di setiap ayat dan bertanya berkaitan dengan apa ayat ini dan bagaimana maksud ayat ini" ${ }^{16}$

Karakteristik yang paling penting pada tafsir era ini adalah bahwa tafsir pada periode ini mulai mengalami hal-hal berikut: ${ }^{17}$

1. Mulai disusupi kisah-kisah isräiliyāt.

2. Masih dalam bentuk ilmu yang diajarkan langsung ataupun periwayatan separti corak yang ada pada zaman sahabat, walaupun pada masa ini lebih kepada periwatan individuindividu dimana setiap kota mempunyai sumber ataupun imam masing-masing.

${ }^{15}$ Muhammad Ḥusain al-Dhahabi, al-Tafsìr wa al-Mufassirūn, Maktabah Wahbah, Qāhirah, 2000, jil.1, hlm. 73.

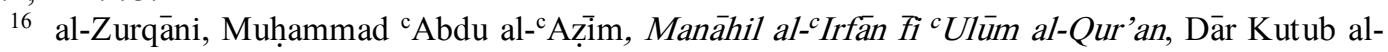
'Ilmiyyah, Bayrūt, 1996, jil.1, hlm.22-23.

${ }^{17}$ Muḥammad Ḥusain al-Dhahabi, al-Tafsìr wa al-Mufassirūn, jil.1, hlm. 73 
3. Tampak mulai muncul bibit-bibit perbedaan mazhab

4. Mulai dikenal perbedaan-perbedaan tafsir yang sebelumnya tidak dikenal di periode sahabat.

Para mufassir dari kalangan tābicīn tersebar di berbagai lokasi. Tābicīn Mekah separti sacīd ibn Jubayr, Mujāhid ibn Jabr, 'Ikrimah Maula ibn ' Abbās, Ṭāwūs ibn Kaisān al-Yamāni dan ${ }^{\mathrm{c} A t a ̣ ~ i b n ~ A b i ~ R a b a ̄ h ~ m e r i w a y a t k a n ~ d a r i ~ I b n ~}{ }^{\mathrm{c} A b b a ̄ s . ~ T a ̄ b i c i ̄ n ~ M a d i n a h ~}$ meriwayatkan daripada Ubayy ibn $\mathrm{Ka}^{\mathrm{c}} \mathrm{ab}$, diantaranya: Zayd ibn Aslam, Abu al- ${ }^{\mathrm{c}}$ Aliyah dan Muḥammad ibn Kacab al-Quraẓi. Tābicīn Iraq separti ${ }^{c}$ Alqamah ibn Qays, Masrūq ibn al-Ajdac ${ }^{c}$, al-Aswad ibn Yazid, Murah al-Hamdāni, ${ }^{c} \bar{A} m i r$ al-Syacbiy, Hasan al-Bașri dan Qatādah al-Sadūsi meriwayatkan daripada ${ }^{c}$ Abdullāh ibn $\operatorname{Mas}^{c} \bar{u} d .{ }^{18}$

Perjalanan tafsir dari zaman sahabat dan tābicin kepada kita hanyalah melalui (pencatatan dan pembukuan). Memang ada buku tafsir yang sekarang sudah diterbitkan, yaitu Tafsir Mujāhid, akan tetapi buku tafsir ini pada kenyataannya bukanlah ditulis oleh al-Imam Mujahid sendiri akan tetapi dikumpulkan dan diriwayatkan oleh Abū Bisyr Warqā ibn 'Umar dan Ḥumaid ibn Qays dari Ibn Abī Najịh dan 'Isā ibn Maimūn daripada Ibn Abì Najị. ${ }^{19}$

Periode ketiga, tafsir mamasuki zaman kodifikasi. Periode ini dimulai di akhir pemerintahan Bani Umayyah dan awal masa pemerintahan ${ }^{\mathrm{c}}$ Abbasiyah. Demikianlah tafsir berkembang dan kitab-kitab yang dikarang mulai menampakkan aliran-aliran yang berbeda-beda. Istilah-istilah ilmiah mulai terbakukan di dalam ungkapan-ungkapan alQur'an, hingga akhirnya tampaklah warna filsafat dan sains dalam khazanah tafsir, begitu pula gaya sufi dan berbagai aliran dan sekte mulai tampak dengan jelas. ${ }^{20}$

Karya tafsir termasuk yang paling tua yang sampai ke tangan generasi sekarang dan ditulis oleh pengarangnya sendiri adalah sebahagian dari kitab al-Wujūh wa alNazāir karya Muqātil ibn Sulaimān al-Balkhi seorang tābici al-tābicīn. Di dalam karya tafsirnya, Muqātil menyebutkan beberapa orang mufassir dari kalangan tābi ${ }^{\bar{c} i n}$ separti

18 Mūsā Syāhīin Lāsyīn, al-Laāî̉ al-Ḥisān fì ${ }^{c}$ Ulūm al-Qur'ān, Dār al-Ta' 'iif, Miṣr, 1968, hlm. 365367.

${ }^{19}$ Ibn al-Nadim, Muhammad ibn Ishāq, al-Fihrisat, Dār al-Macrifah, Bayrūt, 1978, jil.1, hlm.50.

${ }^{20}$ Muḥammad Ḥusain al-Dhahabi, al-Tafsìr wa al-Mufassirūn, Maktabah Wahbah, Qāhirah, 2000, jil.1, hlm. 108. 
Sa ${ }^{\bar{c} i d}$ ibn Jubair, Mujāhid ibn Jabr dan al-Ḍaḥ̣āk ibn Muzāḥim. Sa ${ }^{\bar{c}} \bar{d}$ ibn Jubayr dan

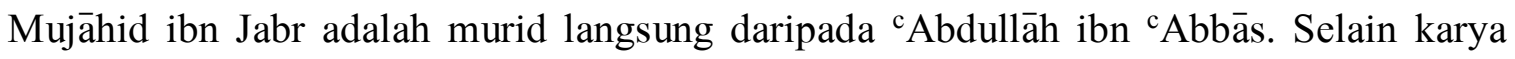
tersebut, Muqātil juga menulis beberapa karya tafsir yang lain separti Tafsìr alKhamsumi'ah āyah, kitab Mutasyābih al-Qur'ān, kitab Nawādir al-Tafsìr dan al-Tafsìr al-Kabir.$^{21}$

Bagaimanapun, sejak dari abad pertama sampai abad ketiga hijriyah, dari berbagai kitab tafsir al-Qur'an belum ada yang memuat tafsir al-Qur'an secara utuh. Penafsiran al-Qur'an secara keseluruhan baru bermula pada abad keempat hijriyah. Ini pertama kalinya dipelopori oleh Ibn Jarīi al-Ṭabari yang menulis Jāmic al-Bayān fi Tafsìr al-Qur'ān. Di dalam karyanya, al-Imām al-Ṭabari mengumpulkan berita dari para pendahulunya yang berkaitan dengan al-Qur'an. Beliau menggunakan sistim isnād untuk menafsirkan al-Qur'an dengan tujuan agar penafsiran itu tidak sewenang-wenang dan tetap bersandar kepada penafsiran yang dapat dipertanggung jawabkan. Dalam menafsirkan al-Qur'an, Imam al-Ṭabari mengumpulkan berbagai hadis, pernyataan para sahabat dan tābi ${ }^{\bar{i}} \bar{n}$ dengan menyebutkan riwayat dan sanadnya walaupun banyak dari riwayat dan sanad tersebut tidak șahīh. Akan tetapi hal tersebut menurut al-Zurqānī tidak mencacatkan nilai ilmiah tafsir tersebut, justeru dengan menyebut riwayat dan sanad beliau menyerahkan kepada pembaca untuk menilai kekuatan sesebuah hadis dan riwayat yang beliau sebutkan dalam tafsirnya. ${ }^{22}$

Setelah Imam al-Ṭabari, muncul berbagai penekanan pendekatan yang lain ketika menafsirkan al-Qur'an. Penekanan dari aspek bahasa diantaranya dilakukan oleh al-Zajjāj dalam tafsirnya Macānì al-Qur'ān, al-Wāḥidi dan Abu Ḥayyān Muḥammad ibn Yūsuf al-Andalusi dalam tafsirnya al-Bahr al-Muhịt. Dari penekanan sisi teologi, penafsiran dilakukan diantaranya oleh al-Zamakhshari dengan kitabnya al-Kashshăf ${ }^{c}$ an ḥaqāiq ghawāmị̣ a-tanzìl, Fakhrudin al-Rāzi dalam kitabnya Mafätịh al-ghaib, juga alBayḍāwi dengan Anwār al-tanzīl wa asrār al-ta'wìl. Penekanan terhadap aspek hukum dilakukan oleh al-Jaș̣ās dengan karyanya Aḥkām al-Qur'ān, Ibn 'Arabi dengan karyanya Aḥkām al-Qur'ān dan al-Qurțūbi dengan kitabnya yang tersohor al-Jāmic li ahkām al-

\footnotetext{
${ }^{21}$ Ibid, hlm. 253 .

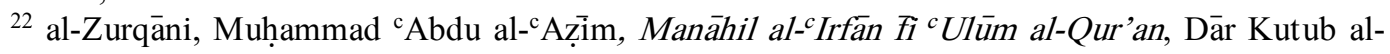
'Ilmiyyah, Bayrūt, 1996, jil.1, hlm.33.
} 
Qur'ān. Penekanan terhadap isyarat-isyarat al-Qur'an yang berhubungan dengan ilmu tasauf misalnya disusun oleh Mạ̣mūd Afandi al-Alūsi dalam kitabnya ${ }^{23}$ Rụh al-ac āni fi tafsir al-Qur'ān al-čzim wa al-sabci al-mathani.

Berbeda dengan al-Dhahabì, dalam sebuah bukunya, Dr.Muhammad 'Affat alSharqāwiyy membagikan gaya dan corak penafsiran sesuai dengan hasil karya dan tingkat interaksi ilmiah setiap periode terhadap tafsir al-Qur'an bukan berdasarkan waktu kemunculannya, yaitu sebagai berikut: ${ }^{24}$

Periode pertama, مرحلة التفسير العملي (tafsir aflikatif): Periode ini adalah zaman Rasul Allah s.a.w dan para sahabat r.a sehingga zaman tabi ${ }^{\bar{c}}$ in. Tafsir periode ini bercirikan kepada pengamalan dan aplikasi dalam kehidupan karena pemahaman penafsiran mereka terhadap al-Qur’an terhasil dari “" (penjelasan dan pemaparan melalui amalan).

Dalam mempelajari makna dan tafsiran setiap ayat dalam al-Qur'an para sahabat tidak berasa puas dengan hanya mengetahui makna dan kandungannya saja, mereka akan berusaha mengamal dan memperaktikkannya dalam kehidupan mereka. Ibn Mas ${ }^{\mathrm{c} u d ~ r . a}$ pernah berkata: " مان الرجل منا إذا تعلم عشر آيات لم يجاوزهن حتى يعرف معانيهن والعمل بهن (Di antara kami apabila ianya mempelajari sepuluh ayat al-Qur'an, maka tidak akan berpindah kepada ayat berikutnya sebelum ia mengetahui arti dan juga mengamalkannya). ${ }^{25}$

Dalam peringkat ini terdapat dua generasi yang sedikit berbeda antara satu dengan yang lainnya: ${ }^{26}$

${ }^{23}$ M.Husain al-Dhahabi menyebutnya sebagai inseklopedia tafsir berharga (mausǘ ah tafsīriyah qayyimah) karena terlalu banyak kitab tafsir yang pengarang nukilkan dalam tafsir tersebut, separti tafsir ibn Atiyyah, Abu Hayyan, al-Zamakhshari, Abu al-Su'ud, al-Baidawi, al-Fakhrurrazi dan kitab-kitab muf tabar lainnya. Ia berharga karena di samping menukil pendapat-pendapat para ahli tafsir sebelumnya, beliau juga banyak memberikan pandangan terhadap setiap pendapat baik dukungan ataupun sanggahan, ataupun membuat pandangan sendiri yang berbeda dengan dalil dan argumenstasi yang kuat. Lihat: Dr.Muḥammad Ḥusain al-Dhahabi, al-Tafsìr wa al-Mufassirūn, Maktabah Wahbah, Qāhirah, 2000, jil.1, hlm. 257.

${ }^{24}$ al-Sharqāwīi, Muhammad 'Affat, Qaụāyyā Insāniyah fí $A^{c}$ māl al-Mufassirīn, Dār al-Nahḍah al${ }^{\mathrm{c} A r a b i y y a h, ~ B a y r u ̄ t, ~ 1980, ~ h l m . ~ 14-108 . ~}$

${ }^{25}$ Muhammad Țāhir, Tărikh al-Qur'an, t.tp, t.th, jil. 1, hlm. 201.

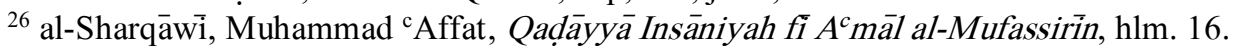


Generasi pertama, generasi yang hanya mencukupkan dengan apa yang mereka dapatkan dari Rasulullah s.a.w dan menolak sama sekali sumber selainnya.

Generasi kedua, generasi yang berpegang pada penukilan dan periwayatan dari Rasulullah s.a.w dan sahabat tetapi terkadang mereka menggunakan sya'ir pra-Islam sebagai alat bantu atau terkadang berijtihad dalam hal yang belum diketahuinya dan tidak mendapatkan riwayat dari Rasul s.a.w. Ibn ${ }^{\mathrm{c}} \mathrm{Abbas}$ adalah salah satu perintis aliran yang kedua ini. ${ }^{27}$ Dalam pandangan al-Syarqāwi, tafsir al-Ṭabāri berjudul Jāmic al-Bayān fî Ta'wìl ày al-Qur'an dianggapnya sebagai contoh dari periode tafsir ini jika dilihat dari segi penukilan, kebahasaan, dan pembukuannya. Hal ini disebabkan kitab ini benarbenar kitab kompilasi $\left(j \bar{a} m i^{c}\right)$ dan dianggap karya puncak tafsir bi al-ma'tsūr yang menggantikan usaha-usaha penafsiran pertama yang telah hilang dari khazanah umat Islam.

Periode kedua, مرحلة التفسير النظري (tafsir teoritis): Periode sebelumnya begitu perhatian terhadap setiap lafaz dan kosakata dalam al-Qur'an, berbeda dengan periode ini, penafsiran makna utuh atas susunan kalimat setiap ayat al-Qur'an adalah salah satu karakteristik utama periode ini. Juga dengan menafsirkan ayat-ayat al-Qur'an dengan melihat konteks secara keseluruhan dan memperhatikan hubungan keseluruhan antara ayat (الجملة والسياق). Periode ini terjadi pada tiga abad pertama berikutnya. Periode ini disebut juga مرحلة النمو والتطور (periode pertumbuhan dan perkembangan tafsir). ${ }^{28}$

Al-Syarqāwi menjadikan gaya penafsiran Ibn ${ }^{\mathrm{c}}$ Arabi, al-Zamakhsyari, dan alRāzì sebagai contoh periode ini. Dalam periode ini menurutnya penta'wilan menjadi sangat bebas, begitu juga pemikiran rasional berkembang dan mendominasi periode

${ }^{27}$ Imam Ibn al-Jauzi dan banyak ahli tafsir lain menukil sebuah riwayat yang menggambarkan bahwa salah satu manhaj Ibn 'Abbās dalam memahami perkataan-perkataan dalam al-Qur'an diantaranya merujuk kepada perkataan orang Arab Badui. Diriwayatkan oleh Mujahid bahwa Ibn ${ }^{\mathrm{c}}$ Abbās pernah berkata: Aku tidak mengetahui makna fạtir al-samāwāt wa al-arḍ sehingga mendengar dua orang Arab Badwi berselisisih tentang sebuah sumur, salah satu diantara mereka berteriak: Ana fatartuhā, yang bermaksud ana ibtada'tu huprahā (aku yang memulai menggalinya). Sehingga maksud perkataan fațir adalah yang memulakan penciptaanya. Lihat Jamāluddīn ibn Abdul Rahmān al-Jauzìi, Zäd al-Masir fí ${ }^{c}$ Ilm al-Tafsir, al-Maktab al-Islāmī, Bayrūt, 1984, jil. 7, hlm. 472.

28 Ahmad Bazwī alḌāwì, Taṣnif Ahl al-Sunnah li Manāhij al-Tafsīir, Julai 2006. http://www.tafsir.org [27 Februari 2009]. 
kedua ini. Periode ini terlahir ketika dunia Islam sedang dalam tahap peradaban yang memuncak dimana ilmu pengetahuan dalam berbagai bidang telah maju dan mengalami perkembangan yang luar biasa, sehingga salah satu ciri khas periode ini juga adalah kemampuan para mufassir dalam menggali al-Qur'an dengan berbagai bidang ilmu ketika itu sebagai respon tuntutan zaman era kegemilangan. Dalam hal ini lahir sebuah kaidah umum bahwa semakin bertambah banyak pengetahuan penafsir tentang rahsia alam dan manusia maka akan bertambah pula kemampuannya dalam menggali teks alQur'an dan bidang-bidangnya yang sangat luas dan dalam itu. ${ }^{29}$

Periode ketiga, periode kejumudan tafsir (مرحلة الركود): Periode ini mulai abad ketujuh hijriyah sehinggalah zaman kebangkitan modern. Mayoritas yang ditulis pada zaman Mongol dan Utsmani tidak lebih berupa penjelasan (الشرح) atau komentar (التعليق) atau rengkasan (التلخيص) karya tafsir pendahulu mereka. ${ }^{30}$ Sehinggalah periode ini disebut عصر الشروح والحواشى (zaman sharahan dan catatan pinggir). ${ }^{31}$

Hal ini terjadi karena pada zaman tersebut dunia Islam dilanda pergolakan politik dan peperangan yang dahsyat sehingga menurut para ahli sejarah hal ini banyak mempengaruhi peranan para ulama dalam menghasilkan karya-karya ilmiah mereka. Peperangan Salib yang panjang dan kehancuran kota Baghdad di tangan tentera Tatar serta perebutan kekuasaan dalam kerajaan Islam sendiri merupakan penyumbang pertama ke atas kejumudan perkembangan ilmu di dunia Islam. ${ }^{32}$

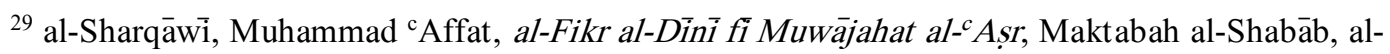
Qāhirah, 1976, hlm. 45

30 Ahmad Bazwī alḌāwī, Taṣnīf Ahl al-Sunnah li Manāhij al-Tafsīi, Julai 2006. http://www.tafsir.org [27 Februari 2009]

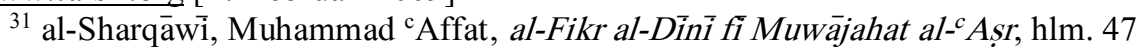

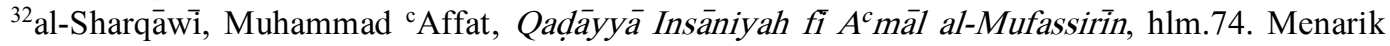
apa yang dicatat oleh Ibn Tagri Bardi mengenai gambaran kehancuran ilmu dan khazanah Islam di Baghdad selepas pembumi hangusannya oleh tentera Tatar yang dipimpin oleh Hulaku Khan pada tahun 556H: Pada ketika itu mereka membakar seluruh kitab dan catatan ilmu pengetahuan tidak ternilai harganya yang tidak boleh dijumpai di belahan dunia manapun. Lihat Ibn Taghrī Bardi, al-Nujūm alZāhirah fí Mulūk Mișr wa al-Qāhirah, t.tp, t.th, hlm, jil.2, hlm. 259 
Al-Syarqāwi memberikan contoh karya tafsir untuk periode ini dengan karya Ibn Katsīr yang mana Ibn Hajar berkomentar atas karangannya, "Ibn Katsìr sibuk ${ }^{33}$ dengan hadis, baik mengkaji matan mahupun perawi sesebuah hadis ketika beliau menggali tafsir, sehingga dengan ini ia lebih layak disebut seorang pakar hadis daripada pakar tafsir". Contoh berikutnya Kitab al-Jawāhir al-Hisān fỉ Tafsìr al-Qur'ān karya imam alTha $a^{c}$ alibī. Menurut Dr. Husein al-Dhahabī, imam al-Tha ${ }^{c} a \bar{a}$ ibìi dalam tafsirnya hanya mengumpulkan pendapat-pendapat orang lain dan tidak mempunyai pengaruh dan nilai ilmiah yang tinggi. ${ }^{34}$

Kitab tafsir karya Imam al-Suyūṭi yaitu kitab al-Dur al-Manthür fí al-Tafsìr bi al-Ma'thür termasuk kitab tafsir dalam periode ini. Dalam mukaddimah kitab, Imam alSuyūṭi menjelaskan bahwa memang sebuah karya tafsir dihasilkan dari nukilan dan kutipan dari kitab-kitab ulama muktabar sebelum zamannya, beliau menulis, ...ketika aku mengarang kitab Turjumān al-Qur'ān, ia merupakan tafsir melalui periwayatan dari Rasul s.a.w dan para sahabat r.a yang terdiri dari empat jilid. Dalam penulisannya, aku banyak mengutip sanad-sanad kitab dengan panjang tanpa membuangnya, ternyata ramai yang tidak punya keinginan yang kuat (untuk mempelajari sanad) dan kebanyakannya ingin yang lebih ringkas dengan tanpa menyebuat sanad-sanad hadis, maka aku merengkaskannya dengan hanya mencukupkan matan, dengan tetap menyebut sumber pengambilan dari kitab muktabar, aku memberikan nama dengan kitab al-Dur al-Manthūr fi al-Tafsìir bi al-Ma'thūr ${ }^{35}$

Salah satu kitab termasuk dalam periode ini adalah kitab Anwār al-Tanzīl wa Ass̄ar al-Ta'wīl karya imam al-Baidāwī. Tafsir ini merupakan ringkasan dari tafsir alKasshäf karya imam al-Zamakhsyari dengan membuang pemikiran-pemikiran muktazilah al-Zamakhsyari, walaupun terkadang al-Baidhāwi sendiri sedikit

${ }^{33}$ Penulis sangat tidak setuju dengan pendapat ini. Ibn Kathir adalah seorang imam ahli tafsir dan ahli hadis, justeru itulah qimah ${ }^{c}$ ilmiyah (nilai ilmiah) dari tafsir ibn Kathir. Pada zaman beliau, mula muncul mereka yang longgar dengan penilaian sesebuah hadis (takhrij) sehingga masyarakat terbiasa dengan meriwayatkan hadis-hadis lemah bahkan palsu.

34 .Muhammad Ḥusain al-Dhahabi, al-Tafsìr wa al-Mufassirūn, Maktabah Wahbah, Qāhirah, 2000, jil.1, hlm. 179

35 al-Suyūṭi, ' ${ }^{c}$ Abdurraḥmān Jalaluddin, al-Dur al-Manthūr fi Tafsìr bi al-Ma'thūr, Markaz Hijr li al-Buhūth wa al-Dirāsāt al-' ${ }^{\mathrm{A}}$ rabiyah wa al-Islāmiyah, Qāhirah, 2003, jil. 1, hlm. 3 
terpengaruh dengan pemikiran-pemikiran al-Zamakhsyarī. ${ }^{36}$ Al-Baidhāwī juga banyak mengambil pendapat imam al-Rāzì dalam tafsirnya Mafátịh al-Ghaib, dan pendapat imam al-Rāgib al-Aṣfahānī dalam Mufradāt al-Qur'ān. ${ }^{37}$ Kitab Madārik al-Tanzīl wa Haqāiq al-Ta’wîl karya imam al-Nasafî antara kitab yang termasuk dalam periode ini, ianya merupakan ringkasan daripada kitab Anwār al-Tanzīl dan al-Kasysyäf.

Periode keempat, periode tafsir zaman modern: Periode ini mempunyai karakteristik yang sangat berbeda dengan periode-periode tafsir sebelumnya. Karakter dan ciri utama periode ini adalah perhatiannya yang besar terhadap permasalahan manusia modern dan penyelesaianya. Ketika mencoba menghubungkan berbagai permasalahan dalam alQur'an (قضايا قرآنية) dengan arus pemikiran semasa (موجات العصر), mufasir terdahulu kebanyakannya hanya menggunakan pendekatan teori dan pemikiran (النظري الفلسفي) sehingga yang muncul kemudian adalah terhad kepada pertentangan pemikiran ( الصراع (الفكري). Berbeda dengan mufassir modern, mereka banyak menggunakan pendekatan praktikal dan langsung kepada permasalahan serta penyelesaiannya. Salah satu ciri dan gaya penafsiran periode ini juga adalah sedikitnya perhatian mereka dalam mengupas ayat dari sudut bahasa dan sastera, sebaliknya langsung kepada tujuan serta pengajaran sesebuah ayat. 38

Para intelektual Islam modern lebih tertarik dengan upaya menjelaskan nilai-nilai al-Qur'an secara kemasyarakatan demi mengukuhkan akidah dan al-Qur'an untuk kehidupan masyarakat manusia sesuai dengan perbedaan generasi dan daerahnya. Kenyataan ini terungkap dalam dua aliran penafsiran di abad modern ini.

${ }^{36}$ Muhammad Husain al-Dhahabi memberikan salah satu contoh ketika al-Baiḍāwi menafsirkan ayat 275 surat al-Baqarah: penjelasannya al-Baidāwi mengatakan bahwa tafsiran pemakan harta riba akan dibangkitkan separti seorang yang dirasuk jin (al-masri $\overline{u^{c}}$ ) hanyalah berdasarkan 'sangakaan' masyarakat belaka. Hal tersebut menurut beliau menunjukkan gejala-gejala $i^{c} t i z a \bar{l}$ dan sama dengan pendapat al-Zamakhshari bahwa jin tidak boleh memberikan pengaruh kepada manusia secara hissiy (boleh diindera). Hanya dalam bentuk penyesatan dan godaan. Lihat: ${ }^{36}$ Dr.Muḥammad Ḥusain al-Dhahabi, al-Tafsir wa al-Mufassirūn, jil. 4 hlm. 55

37 Muhammad Ḥusain al-Dhahabi, al-Tafsìr wa al-Mufassirūn, Maktabah Wahbah, Qāhirah, 2000, jil.1, hlm. 211-212

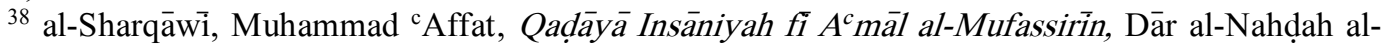
${ }^{\mathrm{c}}$ Arabiyyah, Bayrut, 1980, hlm. 80-81 
Pertama, aliran yang berkeinginan menghidupkan kembali pemahaman sosial kemasyarakatan dalam tafsir al-Qur'an. Tujuan mereka adalah mencapai standar Islam yang dapat digunakan para intelektual muslim dalam menetapkan hukum bagi nilai-nilai baru yang datang dari luar dan mengambil manfaatnya serta menapisnya tanpa harus mengunci diri dari perkembangan dunia modern. Inilah yang kemudian hari dikenal dengan sebutan corak tafsir sosial (لون التفسير الاجتماعي) yang dipelopori oleh syaikh Muhammad 'Abduh dan muridnya Sayyid Rasyid Ridha dari madrasah pemikiran tafsir al-Manār. Aliran ini banyak mengambil berat tentang realiti dan keadaan sosial masyarakat yang dihubungkan dengan hidayah al-Qur'an dengan menghidupkan slogan الإسلام هو الحل (Islam sebagai solusi). Unsur-unsur politik juga banyak disinggung oleh aliran ini, seumpama usaha membebaskan negeri-negeri Islam dari penjajahan dan pemimpin-pemimpin zalim serta menyeru kepada kesatuan negara-negara Arab dan Islam. ${ }^{39}$

Salah satu contoh yang boleh menunjukkan kepedulian dan perhatian aliran tafsir ini terhadap permasalahan umat Islam modern adalah separti yang dihuraikan oleh syaikh Muhammad ${ }^{\mathrm{c} A b d u h}$ dalam tafsirnya al-Manār ketika menjelaskan tafsir surat alMāidah ayat 2:

Umat Islam pada periode pertama adalah satu kelompok yang saling tolong-menolong dalam kebaikan dan takwa, tanpa diikat dengan sebuah perjanjian dan aturan manusia separti zaman sekarang, sebab mereka merasa perjanjian dan aturan Allah (Islam) di atas segalanya:亡 أ kita tidak mudah untuk diikat dengan perjanjian Allah, maka kita perlu kepada sebuah aturan dan perjanjian antara satu dengan yang lain melalui organisasi kemasyarakatan agar ada ikatan antara umat Islam, karenanya apabila umat Islam zaman sekarang ingin hidup mulia wajib ke atas mereka mendirika organisasi, ormas ataupun lembaga kemasyarakatan lainnya yang islami, baik organisasi agama, bantuan ataupun ilmiah. Para ulama dan cerdik pandai diharapkan memberikan tumpuan kepada perkara ini,

\footnotetext{
${ }^{39}$ Ibid., hlm. 82
} 
walaupun tidak ada ulama tafsir yang memberikan tafsiran separti ini, sebab mereka belum terfikir bahwa inilah salah satu cara umat Islam melalukan iṣlah urusan mereka, baik urusan duniawi mahupun ukhrawi. ${ }^{40}$

Aliran kedua, aliran yang mempunyai corak menghubungkan teori-teori sains modern dengan teks al-Qur'an. Tujuannya adalah menghimpun dan menyatukan kembali identiti peradaban muslim setelah sebelumnya terpecah belah. Inilah yang kemudian dikenal dengan nama التفسير العلمي (corak tafsir saintifik)

Petunjuk al-Qur'an berlaku universal dan komprehensif untuk semua manusia di setiap zaman dan tempat. Oleh sebab itu, penafsiran al-Qur'an dengan metode yang menarik hati dan memotivasi manusia untuk merenungi kebenarannya, serta terbebas dari kongkongan khurafat dan mitos perlu dilakukan oleh para ulama untuk menyampaikan risalah Islam. Al-Qur'an mengandungi prinsip-prinsip keimanan yang ditegakkan dengan argumentasi dan hujah-hujah nyata menjawap segala tohmahan dan cabaran orang-orang yang tidak mempercayai kebenaran al-Qur'an. Salah satu burhān (argumentasi) al-Qur'an menyahut cabaran mereka adalah dengan memaparkan tandatanda kebesaran Allah bersifat kawniyyah baik dalam diri manusia maupun alam semesta. Inilah intisari hidayah al-Qur'an yang dengannya dan untuknya al-Qur'an itu diturunkan oleh Allah swt. Firman Allah swt surat Fushshilat ayat 43:

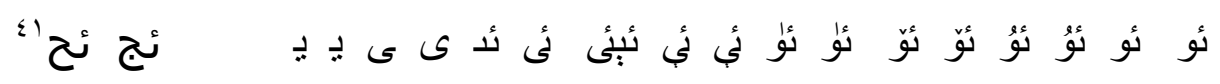

Artinya: "Kami akan perlihatkan kepada mereka tanda-tanda kekuasaan Kami di merata-rata tempat (dalam alam yang terbentang luas ini) dan pada diri mereka sendiri, sehingga ternyata jelas kepada mereka bahwa al-Quran adalah benar. Belumkah ternyata kepada mereka kebenaran itu dan belumkah cukup (bagi mereka) bahwa Tuhanmu mengetahui dan menyaksikan tiap-tiap sesuatu?."

Di dalam al-Qur'an terdapat kira-kira 800 ayat-ayat kawniyyah dalam hitungan Muhammad Ahmad al-Ghamrawi dan menurut Prof. Zaghlul al-Najjar ada 1000 ayat

\footnotetext{
${ }^{40}$ Muhammad 'Abduh, tafsìir al-Manār, Dār al-Manār, Miṣr, 1367H, jil. 6, hlm. 131

${ }^{41}$ Al-Qur' an, Fuș̣ilat 41:53
} 
yang jelas (صارح) dan ratusan lainnya yang tidak jelas (غير صارح) yang berhubungan dengan fenomena alam semesta. ${ }^{42}$

Banyak ayat al-Qur'an yang mengandungi isyarat ilmiah. Dengan penafsiran ayat-ayat tersebut secara saintifik akan memudahkan penyebaran dakwah di abad modern ini. Akan tetapi sebaliknya, penafsiran yang bertentangan dengan hakikat ilmiyah dan hanya bersandarkan kepada periwayatan yang lemah dan palsu bahkan riwayat-riwayat isrāiliyāt hanya akan menambah manusia jauh dari petunjuk al-Qur'an.

Diantara contoh riwayat israìliyāt yang bertentangan dengan fakta ilmiyah adalah tafsiran perkataan $\mathrm{Ra}^{\mathrm{c}} \mathrm{d}$ dengan malaikat yang menggiring $\mathrm{awan}^{43}$, suara yang dikeluarkan $\mathrm{Ra}^{\mathrm{c}} \mathrm{d}$ adalah suara tasbihnya, sementara Barq adalah dampak dari cemeti yang dipakai $\mathrm{Ra}^{\mathrm{c}} \mathrm{d}$ untuk menggiring $\mathrm{awan}^{44}$. Bumi adalah dataran yang berada di atas hūt (ikan paus) ${ }^{45}$. Dan banyak contoh tafsiran yang penuh mitos dan ketinggalan zaman, karena semata bergantung periwayatan dan tidak mengaitkannya dengan fakta ilmiah modern. Tentu saja ketika seorang da'i di masyarakat negara maju ditanya tentang hal semacam ini lalu memberikan jawapan sesuai penafsiran ulama klasik maka akan menjadi bahan ketawa dan cemuhan serta merugikan citra Islam yang berwatak ilmiah dan progresif.

Ada beberapa definisi yang diberikan oleh beberapa pakar ilmu tafsir tentang tafsir cilmi ini, diantaranya:

1) Definisi yang diajukan oleh Prof. Amin al-Khuli yaitu "tafsir yang memaksakan istilah-istilah keilmuan kontemporari dalam menafsirkan al-Qur'an, dan berusaha menyimpulkan berbagai ilmu dan pandangan-pandangan falsafah dari penafsiran itu". ${ }^{46}$

2) Definisi yang diajukan oleh Dr. Muhammad Ḥusein al-Dhahabì yaitu "tafsir yang berusaha mencari padanan teori dan istilah-istilah sains-keilmuan dalam al-Qur'an

42 Fahmi Salim, MA, Tafsir Saintifik Isyarat-isyarat Ilmiah dalam Al-Qur'an, Mei 2008. http://ikadi.org/artikel/kajian/tafsir-saintifik-isyarat-isyarat-ilmiah-dalam-al-quran-1211935784.html [7 Mei 2009]

${ }^{43}$ al-Ṭabari, Muhammad ibn Jarìr, Jāmí al-Bayān fi Ta’wīl Ay al-Qur'an, Muassasah al-Risālah, t.tp, 2000, jil.1, hlm.338

${ }^{44}$ Ibid., hlm. 343

${ }^{45}$ al-Suyūtịi, 'Abdurraḥmān Jāluddìn, al-Dur al-Manthür fí Tafsìr bi al-Ma'thūr, jil.12, hlm. 307

${ }^{46}$ Amin Khauli, Manāhij al-Tajdì fi al-Naḥw wa al-Balāgah wa al-Tafsìr wa al-Adab, Dār alMacrifah, t.tp, 1961, hlm. 287 
dengan mengerahkan segala daya untuk menyimpulkan berbagai masalah keilmuan dan pandangan falsafah dari al-Qur' an". ${ }^{47}$

Kedua definisi di atas tampak sama, dan dapat diberikan komentar dalam dua hal: Pertama, kedua definisi tersebut terkesan memandang sebelah mata gaya tafsir saintifik, sebab memberi kesan bagi orang awam yang membaca definisi itu bahwa corak tafsir ini dinilai telah menundukkan al-Qur'an ke dalam teori-teori sains yang biasanya berubah-ubah. Sememangnya sosok Amin Khuli dan Muhammad Husein al-Dhahabi ini dikenal berada di barisan ulama yang tidak setuju dengan corak tafsir ini ${ }^{48}$. Kedua, definisi tersebut tidak mampu menggambarkan konsep yang sebenarnya diinginkan para pendukung tafsir ilmi. Para pendukungnya tidak pernah berkeinginan untuk memaksakan istilah-istilah keilmuan modern kepada nas al-Qur'an, atau menundukkan nas al-Qur'an itu kepada teori-teori sains yang selalu berubah. Apa yang dimaksudkan para ulama pendukung corak tafsir ini adalah berupaya menjelaskan salah satu aspek kemukjizatan al-Qur'an agar mudah difahami oleh manusia modern, terlebih di saat rasa dan cita kebahasaan Arab sudah sangat melemah, di kalangan orang Arab sekalipun. Apalagi kini, ilmu dan sains telah menyerbu seluruh sendi kehidupan umat manusia. Oleh sebab itu kiranya, definisi yang lebih tepat untuk corak tafsir ${ }^{c}$ ilmi dan sesuai dengan realitas di lapangan adalah definisi yang dikemukakan oleh Dr Bakri Syaikh Amin yaitu "tafsir yang berbicara tentang istilah-istilah sains yang terdapat dalam alQur'an dan berusaha sungguh-sungguh untuk menyimpulkan berbagai ilmu dan pandangan falsafah dari istilah-istilah al-Qur'an itu. Definisi lain yang boleh kita kemukakan di sini adalah "tafsir yang diupayakan oleh penafsirnya untuk: 1) Memahami nas-nas al-Qur'an dari sudut sains modern, dan 2) Menyingkap rahsia kemukjizatannya dari sisi bahwa al-Qur'an telah memuat informasi-informasi sains yang amat dalam dan belum dikenal oleh manusia pada masa turunnya al-Qur'an, sehingga ini menunjukkan

\footnotetext{
${ }^{47}$ Muhammad Ḥusain al-Dhahabi, al-Tafsìr wa al-Mufassirūn, jil.1, hlm. 349

${ }^{48}$ Ibid., hlm. 359
} 
bukti lain akan kebenaran fakta bahwa al-Qur'an itu bukan karangan manusia, namun ia bersumber dari Allah s.w.t, pencipta dan pemilik alam semesta ini. ${ }^{49}$

Bagi penulis, tafsir al-Qur'an yang dihubungkan dengan perkembangan sains dan teknologi selari dengan perkembangan semasa amatlah berharga, bukan saja dapat menggali lebih dalam isi kandungan al-Qur'an yang maha luas, juga separti disebutkan di atas, ianya akan mempermudah ketika kita berdakwah kepada golongan orang bukan Islam terutamanya kaum interlektual dan masyarakat terpelajar. Kisah masuk Islamnya Prof.Maurice Bucaille ${ }^{50}$ adalah salah satu contoh nyata bagaimana bukti saintifik yang sesuai dengan al-Qur'an menjadikan seseorang yakin akan kebenaran Islam.

\section{Asālib al-Tafsìr (Gaya dan Metode) Penafsiran}

Bila diteliti perihal dinamika tafsir al-Qur'an sejak dahulu sampai sekarang, akan diidentifikasi empat gaya penafsiran yang pernah dipakai untuk menjelaskan ayat-ayat al-Qur'an, yaitu; ijmāli (global), taḥliti (analitis), muqărin (perbandingan), mauḍứ $i$ (tematik). ${ }^{51}$

\subsection{Tafsir ijmāti}

Tafsir ijmali (global) adalah metode penafsiran dengan menjelaskan ayat-ayat al-Qur'an secara ringkas tetapi telah mencukupi keperluan pemahaman tentang ayat tersebut, disuguhkan dengan bahasa popular, mudah difahami dan senang dibaca. ${ }^{52}$ Sistematika metode ijmali ini menuruti susunan ayat-ayat al-Qur'an dengan gaya bahasa yang tidak terlalu jauh dari gaya bahasa al-Qur'an. Diantara contoh tafsir yang termasuk dalam kategori ini adalah tafsir al jalālain. Ciri utama dari metod ini; penafsiran tidak disajikan secara terperinci tetapi rengkas dan umum.

49 Fahmi Salim, MA, Tafsir Saintifik Isyarat-isyarat Ilmiah dalam Al-Qur'an, Mei 2008. http://ikadi.org/artikel/kajian/tafsir-saintifik-isyarat-isyarat-ilmiah-dalam-al-quran-1211935784.html [7] Mei 2009]

50 Ismail Abdul Wahid, Islamnya Profesor Perancis: Prof.Maurice Bucaille, 19 Julai 2008. http://www.forumbebas.com/showthread.php?tid=36509\& [12 Januari 2010]

51 Nasaruddin Baidan, Metodologi Penafsiran al Qur'an, Pustaka Pelajar, Yogyakarta, 2000, hlm. 2 .

52 Ibid., hlm.13 


\subsection{Tafsir $\operatorname{tah} \sqrt{i}{ }_{i}$}

Metode analisis ialah menafsirkan ayat-ayat al-Qur'an dengan mendedahkan segala aspek yang terkandung di dalam ayat- ayat yang ditafsirkan serta menerangkan makna yang tercakup di dalamnya sesuai dengan keahlian dan kecenderungan mufasir yang menafsirkan ayat-ayat tersebut. ${ }^{53}$

Sistematika penafsiran tetap sesuai dengan urutan ayat-ayat dalam mushaf. Tetapi huraiannya telah menyangkut pada kosakata, konotasi kalimah, asbab nuzul, munasabah serta analisa (pendapat) mufasir berkait an ayat tersebut sudah muncul. Pada penjelasannya metode ini dihubungkan dengan tafsiran Nabi s.a.w, sahabat, tabiin, serta pendapat para mufasir lain. Penafsiran ini berusaha menjelaskan makna ayat al-Qur'an secara komprehensif. Di samping itu, metode ini telah menyentuh pada disiplin ilmu penafsir misalnya fiqh, falsafah dan lain-lain.

\subsection{Tafsir muqārin}

Pada dasarnya muqāranah berarti perbandingan. Maka metode komparatif dapat diartikan sebagai; 1] Membandingkan ayat-ayat al-Qur'an yang mempunyai persamaan atau kemiripan redaksi dalam dua kasus atau lebih atau memiliki redaksi yang berbeda bagi satu kasus yang sama. 2] Membandingkan ayat al-Qur'an dengan hadis yang pada lahirnya terlihat bertentangan. 3] Membandingkan berbagai pendapat ulama tafsir dalam penafsiran al-Qur'an. Ciri pokok metode ini adalah dalam metode penafsirannya membandingkan pendapat para ahli tafsir. Jadi dapat dipastikan ruang lingkupnya lebih luas. ${ }^{54}$

\subsection{Tafsir maudữ $i$ (tematik)}

\footnotetext{
${ }^{53}$ Ibid., hlm.31

${ }^{54}$ Ibid., hlm.65
} 
Yang dimaksud metode tematik ialah membahas ayat-ayat al-Qur'an sesuai dengan tema atau judul yang telah ditetapkan. Semua ayat yang berkaitan dihimpun kemudian dikaji secara mendalam dan tuntas dari berbagai aspek yang terkait dengannya, separti asbab nuzul, kosakata, munasabah, majaz kalimat dan sebagainya. Penafsiran ini didukung oleh dalil-dalil atau fakta-fakta yang dapat dipertanggung jawabkan secara ilmiah. Ciri utama metode ini adalah menonjolkan tema judul / topik pembahasan. Dalam sumber yang lain diartikan sebagai "menghimpun ayat-ayat alQur'an yang mempunyai maksud yang sama, dalam arti sama-sama membicarakan satu topik masalah dan menyusunnya berdasarkan kronologi serta sebab turunnya ayat-ayat tersebut, kemudian penafsir mulai memberikan keterangan dan penjelasan serta mengambil kesimpulan." 55

\section{DAFTAR PUSTAKA}

55 Abd al Hayy al Farmawi, Metod Tafsir Mawdhu'iy, PT Raja Grafindo Persada, Jakarta,1994, hlm. 36-37. 
Al-Sabt. Khalid Ibn 'Uthmān. 1421H/2001. Qawăcid al-Tafšrir. Jil.1. t.tp: Dār Ibn c'Affān.

Ibn Manzūr. Muhammad ibn Makram. t.th. Lisān al-c Arab. Jil.5. Bayrūt: Dār Ṣādir.

Al-Zarkasyì. Muhammad bin 'Abdillāh. t.th. Al-Burhān fì ${ }^{c}$ Ulüm al-Qur'ān. Jil.1. Beyrut: Dār al-Macrifah.

Al-Suyūtịi. Jalaluddīn. 1995. al-Itqān fí c'Ulūm al-Qur'an. Jil.2. Bayrūt: Dār al-Kutub alcilmiyyah.

Ibn 'Āsyūr. Muhammad ibn al-Ṭāhir. 1997. Al-Tahrīr wa al-Tanwïr. Jil.1. Tūnis: Al-Dār alSaḥnūn li al-Nasyr.

Thāsy Kubri Zādah. 1985. Miftāh al-Sacādah wa Miṣbāh al-Siyādah fi Mauḍư ăt al-c Ulūm. Jil.1. Dār Bayrūt: Kutub al-cIlmiyyah.

Ibn Taimiyah. Ahmad ibn Abd Halim. 2005. Majmūc Fatāwā. Dār al-Wafā. Jil.33. Riyād: t.pt Muhammad Ḥusain al-Dhahabi. 2000. al-Tafsìr wa al-Mufassirūn. Maktabah Wahbah. Qāhirah

Al-Tabari. Muhammad ibn Jarīr. 2000. Jämic al-Bayān fi Ta'wīl Ay al-Qur'an. Jil.1. t.tp: Muassasah al-Risālah.

Ibn Kathīr. Ismaìl ibn 'Umar. 1999. Tafsìr al-Qur'ān al-c Azím. Jil.2. t.tp: Dār Ṭayyibah.

Al-Rūmi. Fahd ibn Sulaimān. 1419H/1999. Buhüth fi Ușūl al-Tafsīr wa Manāhijih. t.tp: Maktabah al-Taubah.

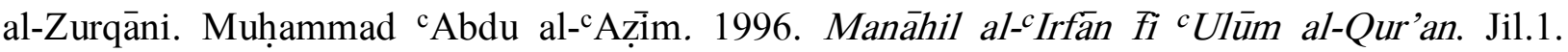
Bayrūt: Dār Kutub al-' Ilmiyyah .

Mūsā Syāhīn Lāsyīn. 1968. Al-Laāîi al-Hisān fíc ${ }^{c}$ Ulūm al-Qur'ān. Miṣr: Dār al-Ta’ lif.

Ibn al-Nadìm, Muḥammad ibn Ishāq. 1978. al-Fihrisat. Dār al-Macrifah. Bayrūt.

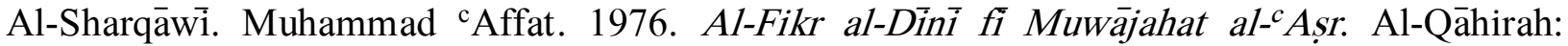
Maktabah al-Shabāb.

Muhammad Ṭāhir. t.th. Tārikh al-Qur'an Jil. 1. t.tp: t.pt.

Muhammad 'Abduh. 1367H/1947. Tafsìr al-Manār. Jil. 6. Miṣr: Dār al-Manār.

Al-Tabari. Muhammad ibn Jarìr. 2000. Jämic al-Bayān fi Ta’wīl Ay al-Qur'an. Jil.1. t.tp: Muassasah al-Risālah.

Al-Suyūṭi. 'A Abdurrahmā̄n Jalaluddin. 2003. Al-Dur al-Manthür fi Tafsìr bi al-Ma'thür. Markaz Hijr li al-Buhūth wa al-Dirāsāt al- ${ }^{\mathrm{C}}$ Arabiyah wa al-Islāmiyah. Qāhirah. Jil. 1. 
Amin Khauli. 1961. Manāhij al-Tajdid fi al-Naḥw wa al-Balāgah wa al-Tafsìr wa al-Adab. t.tp: Dār al-Ma ${ }^{c}$ rifah.

Abd al- Hayy al-Farmawìi. 1994. Metode Tafsir Mawdhu'i. Jakarta: PT Raja Grafindo Persada. 